\title{
The Incidence of Heliothrips sylvanus Faure (Thysanoptera: Thripidae) on Table Grapes
}

\author{
A. Schwartz \\ Viticultural and Oenological Research Institute, Private Bag X5026, 7600 Stellenbosch, Republic of South Africa. \\ Submitted for publication: July 1989 \\ Accepted for publication: August 1989 \\ Key words: Heliothrips sylvanus, table grapes, predaceous mite
}

\begin{abstract}
Thrips belong to a large group of insects that occur on an extensive variety of plants world wide. Many species of thrips are economic pests that have to be controlled by means of chemical pesticides. They possess piercing mouthparts and usually damage the epidermis of plant parts. Some are vectors of important virus diseases, such as spotted wilt disease in tomatoes which is transmitted by Thrips tabaci Lindeman (Borror, DeLong \& Triplehorn, 1976). Several species of thrips are found on table grape vines in the Western Province of which two are potential economic pests, viz. T. abaci and Heliothrips sylvanus Faure (Schwartz, 1987a). T. tabaci feeds on the very young berries and new shoots, whereas $H$. sylvanus has a preference for leaves. At present no knowledge exists on the incidence and seasonal occurrence of $\boldsymbol{H}$. sylvanus on table grapes. As a prerequisite for establishing a practical control program for $\boldsymbol{H}$. sylvanus, it was deemed necessary to obtain this basic information.
\end{abstract}

\section{MATERIALS AND METHODS}

The study was carried out on Vitis vinifera L. cv. Barlinka on two farms (Idylle and Tweespruit), situated at Klein Drakenstein near Paarl, Western Cape Province.

Infestation characteristics

Infestation relative to leaf position on a shoot: On two occasions one month apart (1987-01-28; 1987-02-26) 60 leaves from 20 randomly chosen vines were sampled as follows: 20 leaves from each of three positions on a shoot (basal, middle and apical) were sampled into a jar containing a 70 percent ethanol solution and processed according to the method described by Schwartz (1987b). Larvae and adults of $H$. sylvanus were recorded for each position and the leaves were inspected for feeding damage, viz. a silver and/or bronze colour (percentage of leaves damaged was calculated).

Leaf surface damage: At the height of an infestation, ten vines were chosen at random and 100 leaves were removed at random from each vine. The leaves were carefully examined with the aid of a magnifying glass and the presence of $H$. sylvanus damage to the leaves recorded for both leaf surfaces.

\section{Seasonal occurrence}

Sampling commenced during October, as soon as shoots with leaves had developed sufficiently, and terminated when natural leaf drop occurred. This was carried out at biweekly intervals. Samples were taken from a single vine for each of five plots in a row and for 10 rows, i.e. a total of 50 shoots per vineyard. The three leaves on each shoot were processed according to the method mentioned above. All motile stages of H. sylvanus and natural enemies were noted. In addition, on two occasions during the study, sampled leaves were assessed for damage by $H$. sylvanus as before.

\section{RESULTS AND DISCUSSION}

\section{Infestation characteristics}

Infestation relative to leaf position on a shoot: The results in Table 1 indicate that mature leaves situated at the base and the middle, along the length of a shoot, were the preferred feeding sites during mid-summer. The results further show that, as the preferential sites became limited through feeding damage (bronzing), the thrips population concentrated on the leaves situated closer to the apex.

TABLE 1

Heliothrips sylvanus distribution and damage relative to leaf position on shoots.

\begin{tabular}{|c|c|c|c|c|c|c|c|c|}
\hline \multirow{2}{*}{ Leaf position } & \multicolumn{6}{|c|}{ Sampling date } \\
\cline { 2 - 9 } & \multicolumn{3}{|c|}{ Number of thrips } & & \multicolumn{3}{c|}{ Number of thrips } & \\
\cline { 2 - 9 } & Larvae & Adults & Total & Damage (\%) & Larvae & Adults & Total & Damage(\%) \\
\cline { 2 - 9 } & 47 & 137 & 184 & 95 & 8 & 3 & 11 & 65 \\
\hline Basal & 31 & 149 & 180 & 20 & 178 & 13 & 191 & 55 \\
\hline Middle & 19 & 21 & 40 & 0 & 141 & 6 & 147 & 5 \\
\hline
\end{tabular}

S. Afr. J. Enol. Vitic., Vol. 10 No. 21989 
Leaf surface damage: At the height of infestation it was found that 2,6 percent of the leaf sample had damage symptoms both abaxially and adaxially, whereas 73,4 percent were affected abaxially only.

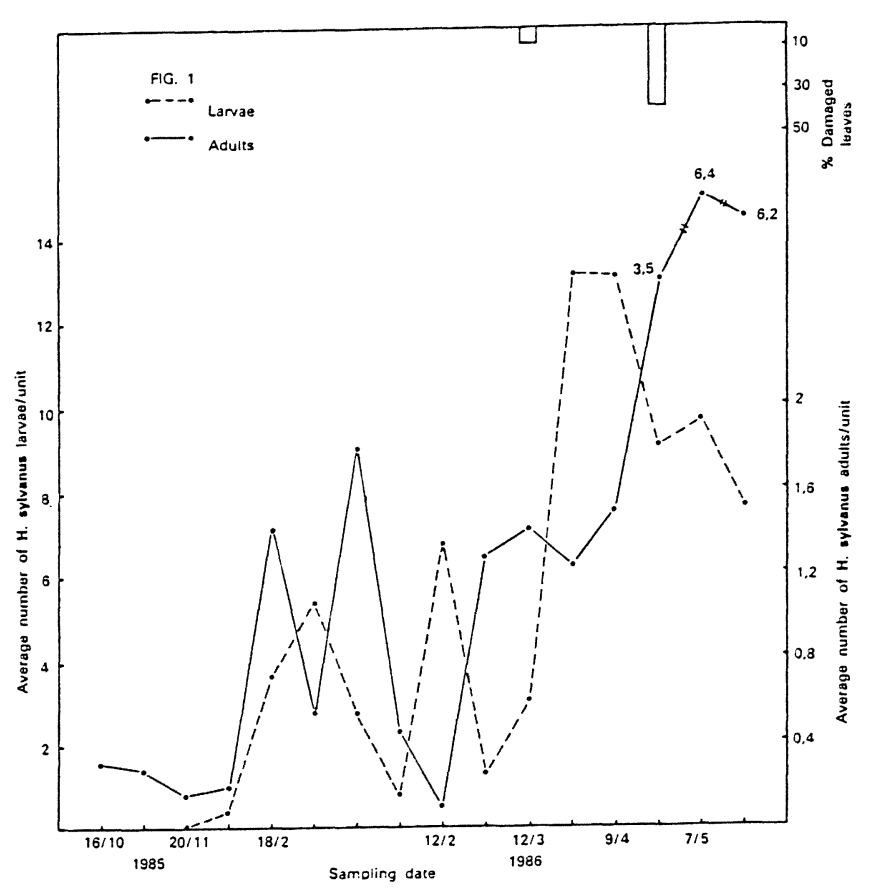

FIGURE 1

Incidence of Heliothrips sylvanus on leaves of Barlinka, Tweespruit, Klein Drakenstein. A unit represents the basal, middle and apical leaves taken from a shoot.

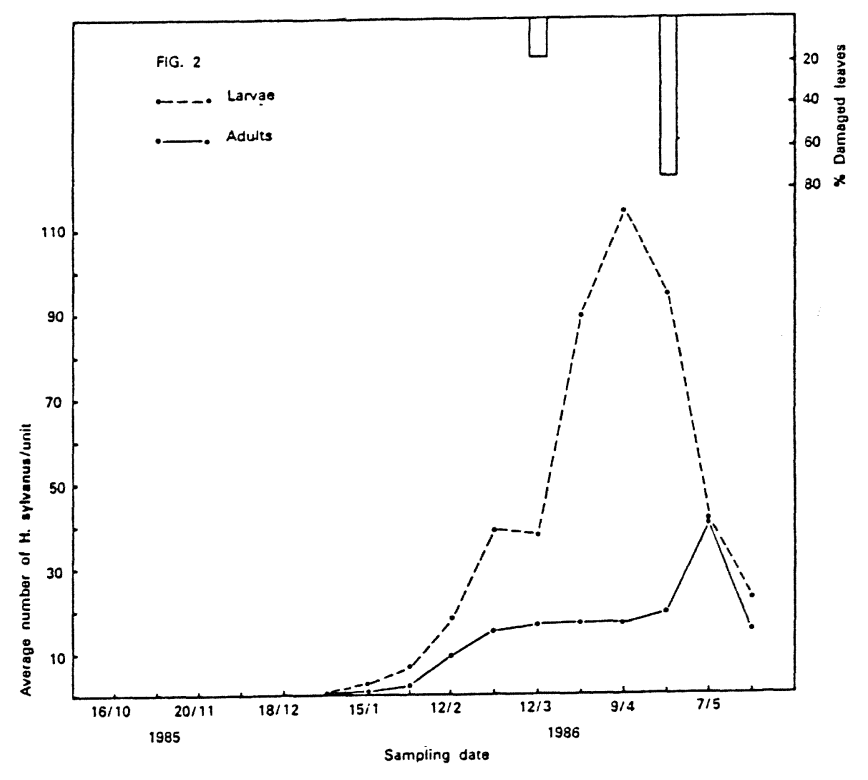

FIGURE 2

Incidence of Heliothrips sylvanus on leaves of Barlinka, Idylle, Klein Drakenstein. A unit represents the basal, middle and apical leaves taken from a shoot.
From the data in Figs. $1 \& 2$ it can be deduced that the damage to leaves increased as the season progressed. On the 12th of March (Tweespruit) 9 percent of the sample leaves (total 150 from three positions on a shoot) had been damaged. This increased to 38 percent at the end of the season (Fig. 1). In the second vineyard (Idylle), the figures were 21 percent and 75 percent respectively for the same dates (Fig. 2). However, the significance of such damage in terms of future growth and crop-set was not established.

\section{Seasonal occurrence}

Small numbers of $H$. sylvanus adults were present on the leaves from October on Tweespruit farm (Fig. 1). A maximum adult population was reached on the 7th of May, followed by a downward trend. The first larvae were recorded at the beginning of December and the numbers oscillated until a peak was reached eight weeks before that of the adults. During the next two weeks the larval population remained constant, whereupon a drastic decline occurred.

In contrast to the situation at Tweespruit in Fig. 1, the thrips population (larvae and adults) at Idylle only commenced during January and gradually developed to a peak (Fig. 2). The time of population peak for adults agreed with that at Tweespruit, viz. 7th of May. The larval populations both peaked early in April. Larval numbers started decreasing four weeks before the adult population. The overall infestation, however, was appreciably higher compared to that of Tweespruit. This is shown by the degree of damage to sampled leaves at the end of the season, i.e. 38 percent (Tweespruit) against 75 percent, (Idylle).

\section{Influence of natural enemies}

The only arthropod that occurred in appreciable numbers was the predaceous mite, Amblyseius addoensis Van der Merwe \& Ryke. This predator appeared on the leaves of the Barlinka vineyards towards the middle of January (Fig. 3). The population demonstrated tremendous growth during March and April, which is in agreement with previous findings on Waltham Cross and Queen of the Vineyard (Schwartz, 1987b). The salient feature is that this population increase developed parallel to that of the pest, $H$. sylvanus, and is a good indication that the latter served as a food source for $A$. addoensis. Observations in the laboratory had confirmed that $A$. addoensis preys on the very young larvae of $H$. sylvanus.

\section{CONCLUSIONS}

Heliothrips sylvanus occurs principally on the abaxial surface of mature leaves of infested Barlinka vines where their feeding causes a silver to bronze colour. Mature leaves situated at the base and middle of the shoot were found to be the choice site for infestation, with the young apical leaves being the least attractive. However, as the season progressed the original leaves became unattractive due to excessive feeding, which caused $H$. sylvanus to concentrate on the middle and apical leaves.

$H$. sylvanus multiplied during the summer months and population numbers reached a peak during autumn. The highest percentage damaged leaves $(75 \%)$ at the end of the season stemmed from the larger thrips population, but the significance of such damage with regard to future growth and 


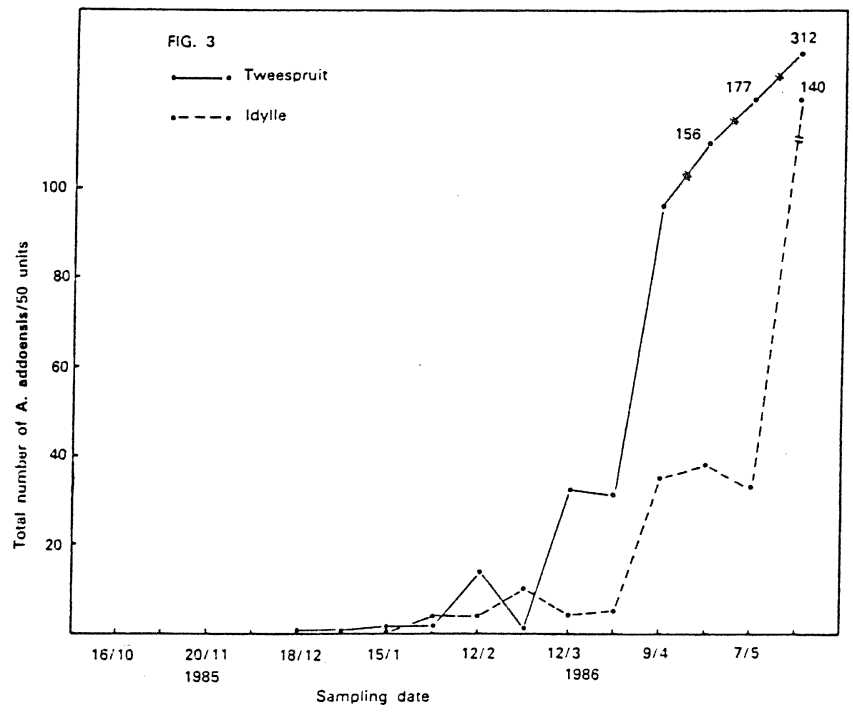

FIGURE 3

Incidence of Amblyseius addoensis on leaves of Barlinka, Tweespruit and Idylle, Klein Drakenstein. A unit represents the basal, middle and apical leaves taken from a shoot. crop-set is not known.

The predaceous mite, $A$ addoensis, was present on the leaves and built up to a peak in conjunction with $H$. sylvanus, due to the fact that the latter was being utilised as a food source. However, A. addoensis was incapable of suppressing the thrips population early in the season so as to prevent considerable damage to the leaves.

It is concluded that with the available knowledge of $H$. sylvanus on Barlinka, future control strategies can be devised

\section{LITERATURE CITED}

BORROR, D.J., DELONG, D.M. \& TRIPLEHORN, C.A., 1976. An introduction to the study of insects (4th edition). Holt, Rinehart and Winston, New York.

SCHWARTZ, A., 1987a. Thrips in table grapes. Farming in South Africa. Viticultural and Oenological Series 1983. VORI, Private Bag X5026, 7600 Stellenbosch, Republic of South Africa.

SCHWARTZ, A., 1987b. Seasonal occurrence of a predaceous mite Amblyseius addoensis Van der Merwe \& Ryke (Acari: Phytoseiidae) on table grapes. S. Afr.J. Enol. Vitic. 8, 78-79. 